\title{
THE ROLE THE STATIC MAXIMIZATION APPROACH PLAYS IN NEOCLASSICAL ANALYSES
}

\author{
Fernando Toboso * \\ Department of Applied Economics, University of Valencia, \\ Av. Tarongers s $n, 46022$ Valencia, SPAIN \\ E-mail: Fernando.Toboso@uv.es \\ Web: www.uv.es/ecoinst \\ Fax: (34) (96) 382-8415
}

\begin{abstract}
This is an article on the methodology of economic thought. The critical assessment of the neoclassical research programme contained here basically comes from the contributions of J.M. Buchanan, Nobel prize winner in Economics 1986. These comments are aimed at pointing out the role that the static maximization approach plays in neoclassical analyses since L. Robbins and P. Samuelson's influential contributions came about after World war II. Just to complement this basic purpose, I present in section 4 the alternative methodological foundations J.M. Buchanan proposes and uses to replace the static maximization approach when building public choice theory, and I sketch in section 5 several personal comments about some explanatory and prescriptive limitations both neoclassical and public choice analyses share. Except in rare and anomalous cases, neither neoclassical nor public choice analyses contain concepts making reference to the non-voluntary or power influences some individuals might exercise over others in their economic interactions.
\end{abstract}


"In a brief treatment it is helpful to make bold charges against ideas or positions taken by leading figures. In this respect I propose to take on Lord Robbins as an adversary and to state, categorically, that his all too persuasive delineation of our subject field has served to retard, rather than to advance, scientific progress." [Buchanan, J.M. (1964), p. 20.]

\section{INTRODUCTION}

In the present article I basically offer an initial insight of a line of criticism currently held against the neoclassical research programme in economics. Though it might appear paradoxical, I will do this by selecting and reorganizing what James M. Buchanan, Nobel prize winner in economics in 1986 and worldwide acknowledged leader of the public choice research programme, has written on the topic. Of course, this is not to say that Buchanan has offered the only or the most significant contribution to this line of critical assessment. Neither can it be said that this is the most crucial of the several lines of criticism formulated against the neoclassical research programme, nor that Buchanan's arguments may not be also subject to a critical assessment such as that which is complementally offered in section $5 .{ }^{1}$ Here,

* In making this article, I benefited from the many ideas I got during my stay at the Public Choice Center, Virginia, USA. Juan A. Tomas Carpi and Juan Fernandez Cainzos commented me on a previous spanish version. A preliminary english version was presented at The Congress of Political Economists, COPE-International, American University of Paris, January 1993, Paris. 
I will firstly attempt to reflect, as accurately as possible, the critical comments J.M. Buchanan offers against the static maximization approach as one of the methodological foundations of neoclassical economics. Secondly, and only as a way to complement this basic purpose of the article, I will explain in section 4 the alternative methodological foundations J.M. Buchanan proposes and uses to replace the static maximization approach, and I will sketch in section 5 some personal comments on the explanatory and prescriptive limitations neoclassical analyses and Buchanan's public choice analyses share.

By the term "methodological foundations" we usually refer to the previous assumptions, the mode-method of analysis, the motivational postulate or model of man, and the principles and other criteria or rules adopted by the researchers in order to elaborate those models and theories that come to be part of a scientific research program ${ }^{2}$. The static maximization approach mentioned above, as a methodological foundation, refers to a set of previous assumptions generally adopted by neoclassical economists in order to endow their explanatory and prescriptive contributions with the homogeneity, consistency, and generality required in the prevailing scientific procedures. Although this behavior is inevitable in every process of research in which we attempt to establish a certain and meaningful descriptive and explanatory order upon the always chaotic, disperse and incomplete set of available observations, not all possible assumptions to be made are necessarily equal in their ability to allow for the most accurate picture of reality to be painted. The researchers might miss the point by adopting simplifying assumptions that lead to the elaboration of an ordered maquette (explanatory models and theories ) which misrepresents reality or misconceives the existing interrelationships between its components. Obviously, they might also do a good job, being able to convince other colleagues that theirs is the most accurate contribution up untill then. On the other hand, their prescriptive contributions or proposals for public action and reform might also be derived from criteria which are subject to general agreement or, by contrast, are generally discredited, to mention two extreme cases only. The main purpose of the present article precisely consists in presenting J.M. Buchanan's comments and arguments about those topics concerning the explanatory and prescriptive neoclassical contributions elaborated upon the static maximization approach.

${ }^{1}$ It must be mentioned here that since the pioneer contribution by Von Neumann, J. and Morgenstem, O.: theory of Games nad Economic Behavior, an increasing number of neoclassical scholars are redirecting their efforts to overcome some of the critical comments contained in the present article.

${ }^{2}$ See Lakatos, I. (1978), pp. 66-71. 


\section{THE ECONOMIC PROBLEM AND THE CONSUMER IN THE SUPERMARKET: the ratmen}

We can start quoting from J.M. Buchanan as follows:

"But let me return to mainstream efforts of economists in the years since World war II. I have no quarrel with the elaboration and refinements of the maximizing models for individual and firm behavior, although I have argued that many of these contributions belong appropriately to home economics or to business administration rather than to political economy."

Those contributions were greatly influenced, in J.M. Buchanan's opinion, by the ideas contained in the classic Lord Robins' book the Nature and Significance of Economic Science ${ }^{4}$, particularly by the persuasive definition of the economic problem as a matter of allocation of scarce means among alternative or competing ends. In J.M. Buchanan's own words: "Once we accept the Robbins formulation of the economic problem(...). Economics comes to be conceptualized as a varied set of exercises, all of which involves the maximization of some appropriately selected objective function subject to the appropriate constraints. ${ }^{5}$ In doing so, the economists approach their subject matter as if individuals always preferred more rather than less and were always confronting choices which were constrained by fixed means, that is, as if economic choices were always made to maximize something in static situations where other participants do not intervene or do so with fixed offers. To refer to this methodological foundation of most neoclassical analyses, J.M. Buchanan and many others use the term static maximization approach. As is well known, an example usually offered in neoclassical textbooks as an extreme case of the Robbins conceptualization of the economist's subject matter is that situation where a consumer (or a housewife, according to most texts) comes to the supermarket with a fixed budget and decides how to allocate it among the many goods available. It must be said, however, that $L$. Robbins does not restrict his approach to be exclusively used for analyzing the behavior of individuals in specific and well-defined situations. In his attempt to remain neutral towards the ends to be maximized, L. Robbins left economics open-ended, so to speak, not only concerning the ends themselves but also concerning the agent to whom the defined economic problem exists. In J.M. Buchanan's own words:

\footnotetext{
3 Buchanan, J.M. (1975), p. 226

${ }^{4}$ Robbins, L. (1932).

${ }^{5}$ Buchanan, J.M. (1976a), p. 203.
} 
"Search him as you will, and you will not find an explicit statement as to whose ends are alternative. His neutrality extends to the point of remaining silent on the identity of the choosing agent". ${ }^{6}$

This conceptualization or approach, so openly defined, could be extended from the analysis of a situation where an isolated individual is choosing how to solve his economic problem to the analysis of that other in which a family group, a local community, or a central government is the entity in charge of deciding, as we are going to see in the next section. To the extent that the analysis elaborated upon the static maximization approach is circumscribed to the scope of individual choice, says J.M. Buchanan, it may be a useful logical theory of choice devoid of empirical content if no argument is specified in the utility function, or it may have some empirical relevance in specific situations similar to the case of the consumer in the supermarket if some arguments are specified ${ }^{7}$. But, when such a specification is complete by means of assigning weights to the different arguments incorporated in the utility function, the static maximizing analysis leads to the elaboration of an image of economic behavior where individual choices look like automaticprogrammed reactions in direct response to stimuli, that is, predictable behavior with a unique pattern of maximizing results easily derived from the mechanical application of certain programming mathematic techniques. J.M. Buchanan states: "Neither the consumer in the supermarket nor the construction engineer faces an economic problem, both face essentially technological problems". ${ }^{8}$ The static maximizing analysis cannot account for, represent or explain those creative choices individuals make in their relationship to each other that J.M. Buchanan calls genuine choices or exchanges. Those choices are subject to fixed constraints, but also to variable constraints that may be changed in the process of making the exchange or negotiating the deal. Those choices are characterized by the participation of two or more persons who interact, make consecutive offers, and negotiate the terms of the exchange in response to the offers, counteroffers, and strategic positions taken by the other participants. To build an accurate explanatory analysis of those creative economic choices requires you to replace the static maximization approach by an exchange approach, that is, a strategic maximization approach. And that is so, in J.M. Buchanan's opinion, both for the case of economic choices taking place in markets-private sector and those other taking place in political institutions-public sector, as we are going to see in section 4 . He also states:

\footnotetext{
${ }^{6}$ See Buchanan, J.M. (1964), p. 20.

${ }^{7}$ See Buchanan, J.M. (1978), p. 109; and Buchanan, J.M. (1960), pp. 64-5.

${ }^{8}$ Buchanan, J.M. (1964), p. 26.
} 
"But once man is conceived in the image of an artifact, who constructs himself through his own choices, he sheds the animalistically determined path of existence laid out for him by the orthodox economist' model". ${ }^{9}$

To the extent that the severe explanatory limitations of the static maximizing models are recognized and its relevance circumscribed to some specific situations where men behave in a way not much different from that of the programmed rats, J.M. Buchanan has no other point to make than to remark that all those contributions belong more appropriately to a household economics than to this other type of economics he likes to call Political Economy ${ }^{10}$. Nevertheless, referring to Robbins conceptualization ,this author states:

"We were better off, methodologically speaking, in the less definitive Marshallian world when economists did in fact study men in their ordinary business of making a living." ${ }^{11}$

\section{L. ROBBINS, P. SAMUELSON AND THE CONFUSING TURN: the benevolent despot}

It is through the extension of the static maximization approach to the study of social organization and the problems faced by communities of people democratically organized that neoclassical economists and their followers made a research turn which has caused some confusion. Our Nobel prize is explicit on that:

"Where did economics, as a discipline, take the wrong turn ?. My own suggestion is that Lionel Robbins marks a turning point." ${ }^{12}$

This confusion was induced by the lack of identification of the agent to whom the maximization problem exists in that which came to be, since L. Robbins' contribution, the orthodox approach in economic thinking. Definitions like the following from J. M. Buchanan memoirs on M. Freedman were, and continue to be, very popular among economists when they talk about their subject matter:

\footnotetext{
${ }^{9}$ See Buchanan, J.M. (1978), p. 110.

${ }^{10}$ See Buchanan, J.M. (1978), p. 109, and (1975), p. 226.

${ }^{11}$ Buchanan, J.M. (1964), p. 20.

${ }^{12}$ Buchanan, J.M. (1975), p. 225.
} 
"... let me cite Milton Freedman, who says, if I remember his classroom introduction correctly, economics is the study of how a particular society solves its economic problem". ${ }^{13}$

In this definition, the society as a whole is the entity that seems to face the economic problem and whose ends have to be maximized. Although J.M. Buchanan strongly thinks that both M. Freedman and L. Robbins conceive the society in terms of its individual members, and that the definition mentioned above is just a shorthand for saying "how a particular group of individuals who have organized themselves socially solve their economic problem", it is because of this type of definition that it is so easy "to slip across the bridge between personal or individual units of decision and social aggregates". ${ }^{14} \mathrm{~A}$ bridge that is difficult to cross appropriately. If L. Robbins' contributions marked the first turning point, not much later P. Samuelson represented a new impulse to this turn that reoriented the research agenda of the most brilliant neoclassical economists since just after World War II. Through the extension of the static maximization approach to the so-called "theoretical welfare economics", by means of the well-known social welfare function of A. Bergson, P. Samuelson contributed with his influential Foundations of Economic Analysis to the above mentioned turning point ${ }^{15}$. This way, there would assumedly be no significant difference between the conceptualization of the economic problem faced by the isolated Robinson Crusoe and the conceptualization of the economic problem confronted by a community of persons democratically organized. In J.M. Buchanan's own words:

"My strictures are directed exclusively at the extension of this basic maximizing paradigm to social organization where it does not belong. This is the bridge which economists should not have crossed, and that has created major intellectual confusion." ${ }^{16}$

Similar to the maximization of an individual utility function under fixed constraints, welfare economists go on to maximize their previously constructed social welfare functions under the constraints that assumedly restrict the society under investigation, though, in this case, their main purpose is not explanation but prescription, that is, deriving policy proposals. To the extent that this type of theoretical exercise or prescriptive analysis is offered only as a pure logical reasoning in which the analyst applies the static maximizing calculus to a social

\footnotetext{
${ }^{13}$ Buchanan, J.M. (1964), p. 21.

${ }^{14}$ Ibidem, p. 23.

${ }^{15}$ See Buchanan, J.M. (1973), pp. 141-2.

${ }^{16}$ Buchanan, J.M. (1975), p. 226.
} 
welfare function defined by himself on his own and personal value judgements and interpretations, J.M. Buchanan has no objection to make ${ }^{17}$. Even such a theoretical game might have positive effects measured in terms of the pleasure and self-satisfaction experienced by the analyst with the results he gets. But, according to J.M.Buchanan, "error arises when either the analyst or his interpreters consider such results applicable to real-world issues. Analyses of this sort are two dimensions away from realworld relevance. ${ }^{18}$

Leaving for the next section the consideration of one of these two dimensions (how the analyst's value judgements and perceptions affect the social welfare function he deems to be the most representative of the collectivity as a whole, and, consequently, how they affect his policy proposals) it must be emphasized here that the extension of the logic of choice of an individual person to a situation where democratic public choices are made, and no such individual person that maximizes for the whole society exists, leads to a theoretical welfare economics of a "questionable value when it is based on the assumption that he exists". ${ }^{19}$ In such an analysis, the most relevant aspects of the democratic political process are assumed away. In another contribution, J.M. Buchanan states in the same sense:

"Wicksell warned as early as 1896 against the presumption that we, as economists, give advice to the benevolent despot, to the entity that would indeed try to maximize a social welfare function. Wicksell stated that if reform in economic policy is desired, look to the rules through which economic policy get made, look to the constitution itself". ${ }^{20}$

The process emerging from these two turning points just mentioned attracted so many economists all over the world that some other potential economic analyses rested long undeveloped or unknown for most economists, as are the cases of public choice theory, in which men do not are assumed to behave like rats, and constitutional political economy, in which no maximizing benevolent despot is assumed to exist in democratic societies. J.M. Buchanan's conclusion is that one already mentioned in the first quotation of the present article where this author, referring to Robbins, states: "his all persuasive delineation of our subject field has served to retard, rather than to advance, scientific progress".

\footnotetext{
${ }^{17}$ See Buchanan, J.M. (1964), p. 23.

${ }^{18}$ Buchanan, J.M. (1960), p. 75.

${ }^{19}$ Ibidem, p. 76.

${ }^{20}$ Buchanan, J.M. (1983), p. 23.
} 


\section{THE SCIENCE OF POLITICAL ECONOMY VERSUS HOUSEHOLD ECONOMICS AND WELFARE ECONOMICS}

Although the main purpose of the present article is to account for those unknown critical comments of J.M. Buchanan mentioned above, we cannot finish without at least briefly presenting the alternative methodological foundations this author proposes and uses. In the next section we will evaluate both neoclassical and public choice analyses to show some limitations they share because of their methodological foundations.

What, then, should economists do, according to J.M. Buchanan? . What should economic science be?. Our Nobel prize winner responds to these questions as follows:

"My 1962, as well as my 1982, response to this question was to urge that we exorcize the maximizing paradigm from its dominant place in our tool kit, that we quit defining our discipline, our science, in terms of the scarcity constraint, that we change the very definition, indeed the very name of our science, that we stop worrying so much about the allocation of resources and the efficiency thereof, and, in place of this whole set of ideas, that we commence concentrating on the origins, properties, and institutions of exchange, broadly considered". ${ }^{21}$

In other words, in analyzing those decisions over economic resources that take place in both the market and political processes, the static maximization approach, as a methodological foundation, should give its dominant place to what J.M. Buchanan himself calls the exchange approach. J.M. Buchanan, together with other colleagues from the Virginia school, has for many years been applying his own recommendations, analyzing from an exchange approach all those political processes, actions and interactions that take place under the democratic political institutions and rules of western societies. ${ }^{22}$ Although this author does not use the term, his exchange approach may be also labeled a strategic maximizing approach in which two or more agents interact under some fixed and some variable constraints. This makes a difference from neoclassical analyses, though in both cases the agent is assumed to be maximizing. In both cases, whether or not to assume the existence of perfect knowledge on the part of the agents is an option the analysts have, but maximizing analyses may be elaborated assuming the existence

\footnotetext{
${ }^{21}$ Ibidem, p. 20.

${ }^{22}$ An extensive presentation of those contributions may be found in Mueller, D.C. (1979) and (1989). See also Rowley, Ch. (1993).
} 
of less than full information, and even bounded rationality ${ }^{23}$. In spite of the above mentioned differences, public choice analyses elaborated upon a strategic maximization approach share some methodological foundations with neoclassical analyses, such as the homo-economicus motivation assumption and the methodological individualism mode of explanation-analysis ${ }^{24}$. Because of those methodological similarities and differences, J.M. Buchanan himself states that contributions of public choice theory generally "emerge from an extension-application of the tools and methods of the (neoclassical)* economist to collective or non-market decision-making". ${ }^{25}$ And, as such an extension, among others ${ }^{26}$, he points out the replacement of the static maximization approach by the exchange approach. It is possible, of course, to formally express the theories, models and propositions of this new analysis using the formal language of mathematics, but it is the so-called mathematics of the theory of games which is required here. ${ }^{27}$ J.M. Buchanan does not usually use them.

Finally, concerning prescriptive analyses or policy proposals, what options have those economists who reject making and maximizing social welfare functions, according to J.M. Buchanan?. In section 3 we said that this author considered welfare economists' contributions to be two dimensions away from real world relevance. It is the dimension we did not analyze there which must be emphasized here firstly. In this sense, the answer to the above question is that public choice scholars working under the umbrella of constitutional political economy should not hinder the criterion and personal value judgements inevitably needed to develop those prescriptive analyses or proposals for change. This way, they should not get trapped in the objectivist-technocratic stance which leads welfare economists to state that they know which policy actions will increase the well-being of others better that than these others themselves know. In his several contributions to constitutional political economy, J.M. Buchanan proposes and uses the principle of normative individualism $^{28}$ (also labeled contractarianism) as the ultimate criterion upon which

${ }^{23}$ On that topic see the pioneer contributions of Simon, H.A. (1976), (1978), and (1979), and the contributions of the so-called "new institutional economics" such as Williamson, O.E. (1975), (1985), North, D.C.(1989), (1990), (1991a), and (1991b).

${ }^{24}$ An investigation of the role those foundations play in public choice contributions may be found in Toboso, F. (1990b), (1991a), and (1993a).

${ }^{25}$ Buchanan, J.M. (1983), pp. 19-27. See also Buchanan, J.M. (1979), pp. 105-36.

26 Among those other extensions we have to mention the so-called the normative individulism principle considered in sections 4 and 5 of the present article.

${ }^{27}$ See Buchanan, J.M. (1975), p. 229, and (1964), p. 36.

${ }^{28}$ On that topic see Buchanan, J.M. (1985), (1987), (1990), (1991), Brennan, G. \& Buchanan, J.M. (1980), (1985), and Vanberg, V. (1986). See also Toboso, F. (1990a), chapter 9, and (1991b). 
the prescriptive analyses should rest upon. As an operational criterion this author uses the Pareto criterion of efficiency. ${ }^{29}$ To select a criterion among the several options available requires making a value judgement that will inevitably affect the proposals for public action derived from such a criterion, as this author explicitly acknowledges. In constitutional political economy contributions, the ultimate criterion for evaluation requires that every one be considered the best judge of his own well-being. If a public choice scholar wants to take part in the ongoing constitutional reform debate, the most he can do, according to that criterion, is attempt to find those proposals for institutional reform that might be acceptable to those who are affected by the reform. If those proposals get an explicit disapproval by most affected participants (despite the ever present scholar's efforts to explain the proposals and persuade participants), the constitutional political economist must acknowledge that he was wrong when thinking that his proposals were Pareto-efficient, and, consequently, he should look for another ones. Therefore, J.M. Buchanan acknowledges that the economist's prescriptive analyses-policy proposals are always influenced by the criterion he adopts and his own personal value judgements and interpretations which come up in the research process of using that criterion. The normative individualism principle assigns to the political economists no more than one vote in the public choice processes required for institutional reform. As must be obvious, J.M. Buchanan also critically assesses the objetivist-technocratic stance generally present among welfare economists when deriving policy proposals from their maximized social welfare functions.

\section{SOME LIMITATIONS SHARED BY NEOCLASSICAL ANALYSES AND BUCHANAN'S PUBLIC CHOICE ANALYSES}

As mentioned in the introduction, the present section is only to point out that none of the two maximizing analyses here investigated (neoclassical-static, public choice-strategic) account for an aspect that may sometimes be present in economic choices. And that is because in both camps an assumption we have not mentioned yet is also made. Economic agents are usually assumed to be free from those coercion and power influences that might come about as a result of other agents' behavior. Except in rare and anomalous cases such as that of the monopoly, in those models and theories we do not find those concepts that allow for the power influences to be shown up. The explanatory analyses elaborated in both the neoclassical static maximizing models and the public choice strategic maximizing ones all show us voluntary actions, interactions or negotiations, that is, voluntary choices and exchanges taking place at the supermarket, at the labor market, or at

\footnotetext{
${ }^{29}$ See Buchanan, J.M. (1959), and Brennan, G. \& Buchanan, J.M. (1985), chapter 2.
} 
the political congress. To refer to this methodological characteristic of those maximizing analyses, we can use the term voluntary conceptualization, by contrast to a power conceptualization such as the one frequently adopted by many political scientists and institutional economists, for example. The image of reality contained in analyses built upon a voluntary conceptualization have to be necessarily different from the image of the same reality contained in analyses built upon a power conceptualization. As I showed in a previous article particularly addressing this comparison $^{30}$, although J.M. Buchanan has always been doing research upon a voluntary conceptualization, he has explicitly acknowledged on several occasions that an analysis built upon power concepts may yield relevant insights on many aspects of the economic processes taking place both in market and political institutions. He once stated:

"I make this categorical distinction largely to suggest that the perspective of economics-as-exchange, with its natural extension to institutional settings in which persons interact collectively, offers (...) a different way of looking at political process, different in kind from that way of looking which emerges from the politics-as-power perspective.(...) There are, nonetheless, major contributions to be made by the extension of both perspectives across the whole spectrum of institutions. In this sense, the public choice perspective on politics becomes analogous to the economic power perspective on markets." ${ }^{31}$

Concerning the prescriptive contributions of both welfare economics and constitutional political economy, it must be said here that those assessments made and policy proposals derived are not only influenced by the criterion for evaluation and prescription adopted in each case, and the value judgements and interpretations the scholars make in the process of using it (as we have already mentioned in previous sections), but also by the voluntary conceptualization explicitly or implicitly adopted in the explanatory analysis of that phenomenon or institution which has to be evaluated and, if so, reformed. The image one gets from that phenomenon which is going to be evaluated greatly affects the result of the evaluation process and the proposals for reform offered, even if the same criterion for evaluation is used. ${ }^{32}$ If power concepts are used and the efficiency criterion is replaced by, for example, the social value criterion adopted by many institutional economists, the assessments

${ }^{30}$ Toboso, F. (1992b).

${ }^{31}$ Buchanan, J.M. (1983), p. 22.

${ }^{32}$ An example of a maximizing analysis built upon concepts of individual power in which a particular criterion of efficiency is adopted may be found in Anisi, D. (1992). 
made and policy proposals derived may be radically different from those elaborated by welfare economists and public choice scholars. ${ }^{33}$

\section{SUMMARY}

This is an article on the methodology of economic thought. The critical assessment of the neoclassical research programme contained here basically comes from the contributions of J.M. Buchanan, Nobel prize winner in Economics 1986. These comments are aimed to point out the role the static maximization approach plays in neoclassical analyses since L. Robbins and P. Samuelson's influential contributions came about after World War II. Just to complement this basic purpose, I present in section 4 the alternative methodological foundations J.M. Buchanan proposes and uses to replace the static maximization approach when building public choice theory, and I sketch in section 5 several personal comments about some explanatory and prescriptive limitations both neoclassical and public choice analyses share. The content of the article may be summarized as follows. The cases of Robinson Crusoe alone in the island and that of a consumer in the supermarket may be considered good stereotypes of how neoclassical economists generally conceptualize economic processes when building their explanatory analyses upon the assumptions we refer to by the term static maximization approach. Due to this foundation, their models are always more harmonious, mechanical and balanced than the reality they try to represent, explain or predict. In neoclassical models we, as units of analysis, do not seem much different from rats. According to J.M. Buchanan, most economic processes may be better explained by analyses based on an exchange approach, that is, on a strategic maximization approach. The case of Crusoe and Friday interacting to each other is a good stereotype of how economic processes are conceptualized when adopting an exchange approach. In section 5 I state that in both neoclassical and public choice contributions we only see voluntary choices-exchanges. No account is given of the non-voluntary or power influences that might affect the consumer's choices or those others Crusoe and Friday might exercise over each other. According to J.M. Buchanan, L. Robbins and P. Samuelson's contributions may be subject to a more decisive charge. They set the basis for neoclassical economists to extend the static maximization approach to model economic problems faced by politically organized societies. The so elaborated contributions of welfare economics, with its maximizing social welfare functions, represented a research turn that has caused some

${ }^{33}$ Examples of those prescriptive contributions of institutional economists may be found in Tools, M.R. (1979) and (1986), Samuels, W.J. (1979), Samuels, W.J. \& Schmid, A.A. (1981), and Tool, M.R. \& Samuels, W.J. (1989). 
confusion. In democratic societies there is no benevolent despot maximizing what is good for the society as a whole, but a complex political process that should be taken into account. Welfare economists also get frequently trapped in the objectivisttechnocratic stance which leads them to think that they know how to increase the well-being of others better than those other themselves know. In section 5 I state that if it is acknowledged that the criterion for evaluation-prescription has great influence on the policy proposals derived, the objectivist-technocratic stance is no longer defensible, as J.M. Buchanan also admits. Those policy proposals are also greatly influenced by the explanatory analysis elaborated of that phenomenon which is going to be evaluated and, if so, reformed. In the explanatory contributions of all the maximizing approaches mentioned before, we only see voluntary actions and interactions between individuals, not the power influences ones might exercise over others.

\section{REFERENCES}

ANISI, D. (1992)), Jerarquía, Mercado y Valores. Una Reflexión Económica sobre el Poder, Alianza Ed., Madrid.

BRENNAN, G. \& BUCHANAN, J.M. (1980), The Power to Tax, Cambridge University Press, Cambridge.

BRENNAN, G. \& BUCHANAN, J.M. (1985), The Reason of Rules, Cambridge University Press, Cambridge.

BUCHANAN, J.M. (1959), "Positive Economics, Welfare Economics, and Political Economy", in Buchanan, J.M.: FiscalTheory and Political Economy. University of North Carolina Presss 1960, Chapel Hill.

BUCHANAN, J.M. (1960), "Is Economics the Science of Choice?", in Buchanan, J.M.: Economía y Política. Escritos Seleccionados. Universitat de València, 1987, Valencia.

BUCHANAN, J.M. (1964), "What Should Economists Do?", in Buchanan, J.M.: What Should Economists Do?. Liberty Press, 1979, Indianapolis.

BUCHANAN, J.M. (1973), "L.S.C. Cost Theory in Retrospect", in Buchanan, J.M.: Economics. Between Predictive Science and Moral Philosophy. Texas University Press, 1987, Texas.

BUCHANAN, J.M. (1975), "A Contractarian Paradigm for Applying Economic Theory", American Economic Review, vol. 65, n. 2, May.

BUCHANAN, J.M. (1976-a), "Methods and Morals", in Buchanan, J.M.: What Should Economists Do?. Liberty Press, 1979, Indianapolis.

BUCHANAN, J.M. (1976-b), "General Implications of Subjetivism in Economics", in Buchanan, J.M.: What Should Economists Do? Libety Press 1979, Indianapolis.

BUCHANAN, J.M. (1978), "Natural and Artifactual Man", in Buchanan, J.M.: What Should Economist Do?. Liberty Press, 1979, Indianapolis.

BUCHANAN, J.M. (1979), "Politica sin Romanticismos. Esbozo de una Teoría Positiva de la Elección Pública y de sus Implicaciones Normativas", in Buchanan, 
J.M. and others: El Análisis Económico de lo Político. Instituto de Estudios Económicos 1984., Madrid.

BUCHANAN, J.M. (1982), "The Domain of Subjetive Economics: Between Predictive Science and Moral Philosophy", in Buchanan J.M.: Economics. Between Predictive Science and Moral Philosophy. Texas University Press 1987, Texas.

BUCHANAN, J.M. (1983), "The Public Choice Perspective", in Buchanan, J.M.: Liberty, Market, and State. Political Economy in the 1980's. New York University Press, 1986, New York.

BUCHANAN, J.M. (1985), "Constitutional Democracy, Individual Liberty, and Political Equality", in Buchanan, J.M.: Liberty, Market, and State. Political Economy in the 1980's. New York University Press 1986, New York.

BUCHANAN, J.M.(1986), Liberty, Market, and State. Political Economy in the 1980's. New York University Press 1986, New York.

BUCHANAN, J.M. (1987), "The Constitution of Economic Policy", in Buchanan, J.M.: Economics. Between Predictive Science and Moral Philosophy. Texas University Press, 1987, Texas.

BUCHANAN, J.M. (1990), "The Domain of Constitutional Economics", Constitutional Political Economy, vol. 1, $\mathrm{n}^{0} 1$.

BUCHANAN, J.. (1991), The Economics and the Ethics of Constitutional Order, The University of Michigan Press, Ann Arbor.

CENTER FOR STUDY OF PUBLIC CHOICE, Annual Report, años 1987, 1988, 1989, 1990 y 1991.

LAKATOS, I. (1978), La Metodología de los Programas de Investigación Científica. Alianza Editorial, 1983, Madrid.

MUELLER, D.C. (1979), Elección Pública, alianza Universidad, 1984, Madrid.

MUELLER, D.C. (1989), Public Choice II, CambridgeUniversity Press, Cambridge.

NASSON, T. (ed.) (1987), Nobel Prize Winners. I. W. Wilson Company, 1987, New York.

NORTH, D.C. (1989), "A Transaction Cost Approach to the Historical Development of Polities and Economies", Journal of Institutional and Theoretical Econoics, vol. 145, 4.

NORTH, D.C. (1990a), Institutions, Institutional Change, and Economic performance, Cambridge University Press, Cambridge.

NORTH, D.C. (1990b), "A Transaction Cost Theory of Politics", Journal of Theoretical Politics, vol. 2, 4.

NORTH, D.C. (1991), "Towards a Theory of Institutional Change", Quaterly Review of Economics and Business, vol. 31, 4, Winter.

ROBBINS, L. (1932), The Nature and Significance of Economic Science. Macmillan 1932, London.

Press.

ROWLEY, Ch. (1993), The Theory of Public Choice, Cambrige University

SAMUELS, W.J. (1979), The Economy as a System of Power, Transaction Books, New Brunswick.

SAMUELS, W.J. \& SCHMID, A.A. (1981), Law and Economics. An Institutional Perspective, Kluwer-Nijhoff Publ., Boston.

SIMON, H.A. (1976), "From Substance to Procedural Rationality", In Latsis, S.J.: Method and Appraisal in Economics, Cambridge University Press, 1976, Cambridge. 
SIMON, H.A. (1978), "rationality as a process and as a Produc o Though", The American Economic Review, vol. 68, 2, May..

SIMON, H.A. (1979), "Rational Decision Making in Business Organization", The American Economic Review, vol. 69, 4, Sept..

TOBOSO, F. (1990-a), Fundamentos Metodológicos del Programa de Investigación de la Escuela de Virginia. Doctoral Dissertation, Universidad de Valencia, 1990, Valencia.

TOBOSO, F. (1990-b), "Una Teoría de las Instituciones y Procesos Políticos Metodológicamente Individualista: el Programa de Investigación de la Escuela de la Public Choice", Cuadernos de Economía, vol. 18, n. 52, Mayo-Agosto 1990.

TOBOSO, F. (1991a), "El papel del homo-economicus en la Teoría Positiva de la Elección Pública", Cuaderos de Economía, vol. 19, n 55, May-August 1991.

TOBOSO, F. (1991b), "Intercambio Político, Democracia y Sobe- ranía Popular: el Programa de Investigación de la Escuela de la Public Choice", Revista de Derecho Financiero y de Hacienda Pública, vol. 41, n. 212, Marzo-Abril 1991.

TOBOSO, F. (1992), "Metodología de la Teoría de la Elección Pública. La conceptualización de los Procesos Políticos como Procesos de Intercambio", Hacienda Pública Española, nº 122, vol. 3, 1992.

TOBOSO, F. (1993a), "El postulado del homo-economicus y la Economía Política Contitutcional del la Escuela de Virginia", Cuadernos de Economía, vol. 21, n 62, Sept.-Dec. 1993.

TOBOSO, F. (1993b), "On How a Nobel Prize Winner in Economics Acknowledges the Relevance of an Unorthodox Approach Based on Power Concepts", Southern Economic Journal, (in evaluation).

TOBOSO, F. (1993b), "The Images of Institutional Change and their Methodological Foundations", paper presented at the fifth conference of the European Association for Evolutionary Political Economy, October 1993, Barcelona.

TOOL, M.R. (1979), The discretionary Economy. A Normative Theory of Political Economy, Goodyear Publ., Sta. Monica.

TOOL, M.R. (1986), Essays in Social Value Theory, M.E. Sharpe, New York.

TOOL, M.R, \& SAMUELS, W.J. (1989), State, Society, and Corporate Power, Transaction Publ., New York.

VANBER, V. (1986), "Individual Choice and Instituional Constraints". The Normative Element in Classical and Contractarian Liberalism", Analyse \& Kritik, $\mathrm{n}^{\circ} 8$.

VON NEUMANN, J. y MORGENSTEM, O. (1944), Theory of Games and Economic Behavior. Princeton University Press, 1944.

WILLIAMSON, O.E. (1975), Markets and Hierachies: Analysis and Antitrust Implications, Free press, New York.

WILLIAMSON, O.E. (1985), The Economic Institutions Of Capitalism. Firms, Markets, and Relational Contracting, Free Press, New York. 